
https://doi.org/10.30534/ijeter/2019/097112019

\title{
Pyrolysis of Plastic Waste as an Alternative Fuels in Spark Ignition Engine
}

\author{
Sunaryo $^{1}$, Marwan Efendy ${ }^{2, *}$, Sarjito ${ }^{3}$, Nur Saifullah Kamarrudin ${ }^{4}$ \\ ${ }^{1}$ Department of Mechanical Engineering, Universitas Sains Al-Quran, Indonesia, sunaryo@unsiq.ac.id \\ ${ }^{2}$ Department of Mechanical Engineering, Universitas Muhammadiyah Surakarta, Indonesia, \\ Corresponding author : Marwan.Effendy@ums.ac.id \\ ${ }^{3}$ Department of Mechanical Engineering, Universitas Muhammadiyah Surakarta, Indonesia, sarjito@ums.ac.id \\ ${ }^{4}$ School of Mechatronic Engineering, Universiti Malaysia Perlis, Malaysia, saifullah @ unimap.edu.my
}

\begin{abstract}
Plastic waste is a potential alternative energy source in terms of its heating value. In general, plastic is processed by pyrolysis to produce oil, so that internal combustion engines can utilize it in producing power. The purpose of this study is to analyze the characteristics of plastic pyrolysis oil (PPO) and evaluate engine performance and exhaust emissions on the use of fuels resulting from the pyrolysis of plastic waste. In this research, plastic pyrolysis oil was produced through a slow pyrolysis process using raw materials from the type of plastic Low-density Polyethylene (LDPE) and Polyethylene Terephthalate (PET). Experiments were carried out by testing the characteristics of plastic pyrolysis oil (PPO), which included tests of heating value, octane number, density, kinematic viscosity, and flashpoint. The testing of engine performance and exhaust emissions was carried out on a single-cylinder gasoline motor. Testing the use of gasoline fuels was also done as a comparison of the characteristics of the PPO produced. The results showed that the characteristics of PPO have similar physical properties when compared to gasoline fuels. Performance testing of gasoline motors showed that the maximum power PPO of PET plastic types is lower by $3.3 \%$ (5.9 $\mathrm{HP}$ at $7167 \mathrm{rpm}$ ), and the LDPE type is lower by $14.8 \%$ (5.2 $\mathrm{HP}$ at $7030 \mathrm{rpm})$ when compared to gasoline fuel at $6.1 \mathrm{HP}$ at $6619 \mathrm{rpm}$. Maximum torque is 6.77 $\mathrm{Nm}$ at $4314 \mathrm{rpm}$ for the use of PPO of PET plastic-type, and LDPE plastic-type is $5.77 \mathrm{Nm}$ at $5434 \mathrm{rpm}$, where this value is $19 \%$ and $31 \%$ lower than gasoline ( $8.36 \mathrm{Nm}$ at $4428 \mathrm{rpm}$ ). PPO produces exhaust gas emissions in the form of lower HC and $\mathrm{CO}$ and more efficient fuel consumption compared to gasoline. These results indicate that the pyrolysis oil of plastic waste is a promising alternative fuel to be applied to spark ignition engine.
\end{abstract}

Key words: Engine performance, Exhaust Gas Emissions, LDPE, PET and Pyrolysis Plastic Oil Emissions.

\section{INTRODUCTION}

Global plastic production has increased over the years due to a large number of plastic applications in many sectors. Plastic is also an important material for modern existence. Plastic has become a part of daily life in both the household and industrial sectors. Plastic material is a type of polymer compound formed from a series of carbon, hydrogen, and other elements such as chlorine, nitrogen [1] which is lightweight and strong, good durability, corrosion-resistant, fast production processes, and has a design flexibility that is easy to shape.

The continuous demand for plastic causes much accumulation of plastic waste and requires much space for landfills (TPS), which contribute to environmental problems [2]. Global plastic production is estimated at 300 million metric tons annually and growing at a rate of $4 \%$ annually. Over the past three decades, plastic production in large countries has faced explosive growth and reached an average of 129 million tons per year [3]. The World Bank noted that projects using plastics in the world reached 1.3 billion metric tons (Municipal Solid Waste/MSW) produced each year, and are estimated to grow 2.2 billion metric tons per year (MTPY) in 2025. $10 \%$ of the total MSW produced, or 130 MTPY, is plastic. Plastic waste will harm the environment because it is non-biodegradable, does not decompose naturally by micro-organisms, and harms the environment and living things because of the chemical elements contained therein. In addition, a massive buildup of plastic waste can cause pollution in both soil, air, and water.

A large percentage of plastic waste in landfills not only requires a large space but also causes pollution. The accumulation of plastic waste as solid waste will lead to fears of environmental degradation and pollution in most soils [4]. The landfills will not be the right solution for this plastic because it will cause increasingly severe environmental problems. To overcome this problem, the best solution is to find a method to reduce plastic waste by mechanical processes (sorting, grinding, washing), sweltering, or thermal/catalytic cracking [4] or by turning it into useful fuel [1]. Through the right process, plastic waste is a type of waste that is abundantly available and can be used effectively as new energy [3]. 
Efforts to handle plastic waste must be appropriately made [5], including the 3R method, namely reuse, reduce, recycle [6]. Conventional ways such as landfilling and incineration only cause air pollution, are less effective, and risky because combustion arises pollutants from exhaust gas emissions $\left(\mathrm{CO}_{2}, \mathrm{CO}, \mathrm{NOx}\right.$, and $\left.\mathrm{SOx}\right)$ and several other polluting particulates that are harmful to human health [7]. The concept of plastic recycling (recycling of plastic wastes) is then the preferred method because plastic waste is considered a cheap and abundant raw material. Processing into oil, as a liquid fuel, is an attractive alternative way to produce energy sources while improving the quality of handling the plastic waste. A popular recycle technique for processing plastics into liquid fuels is pyrolysis. Pyrolysis is a chemical decomposition and thermal decomposition of molecules under conditions without oxygen [8].

The community's need for fuel oil (BBM) derived from fossils is increasingly growing, causing increasingly depletion of oil and gas reserves. Efforts to find and process alternative fuels must continue. In recent decades, the ethanol-gasoline mixture has been widely investigated and considered a potential alternative fuel for gasoline engines. Investigations related to performance and emissions from fuel use are with various gasoline-ethanol mixture ratios [9]-[11]. Research on the application of pyrolysis oil from plastics shows the thermal efficiency of plastic oil, which is lower than gasoline and diesel fuels and various mixtures thereof [12]. Specific fuel consumption (brake-specific fuel consumption/BSFC) in the use of oil from plastics also looks more efficient. Likewise, with the level of exhaust gas emissions, plastic pyrolysis oil has lower CO, HC, and NOx levels [13] [14], and contains a little sulfur [15].

Efforts to find and process alternative fuels must continue. It is also motivated by the demand for energy on both national and international scale. Very high dependence on BBM must be reduced immediately, and a solution needs to be sought. Plastic is a material made from the element of petroleum so that it can be converted into its original form. The process of pyrolysis of plastic waste can produce plastic oil, charcoal/ash, condensed gas, and non-condensable gas. The operation temperature of plastic pyrolysis is around $450 \mathrm{oC}$ for 75 minutes, showing the most optimal production results, with $80.8 \%$ oil, $13 \%$ gas, and $6.2 \%$ charcoal [16].

The product quality of pyrolysis depends on the type of plastic waste that is put on the pyrolysis reactor and the process parameters (such as temperature, pyrolysis time, and catalyst). The use of plastic pyrolysis to date has been prioritized in the use of liquid fuel products for further processing into several types of fuel oil (BBM). Plastic pyrolysis oil (PPO) has properties similar to petroleum products; therefore, it has the potential to be used in internal combustion engines [17]. Pyrolysis oil from HDPE, LDPE, $\mathrm{PP}$, and PS plastic has a higher heating value than wood and coal [18].

Optimization of engine performance on combustion engines can be done in several ways, including using alternative energy [19], where the testing parameters use engine performance parameters and exhaust emissions [20]. The purpose of this study is to investigate the characteristics of plastic pyrolysis oil properties from PET and LDPE types to determine their eligibility as a fuel. The parameters studied in the engine performance test were the amount of power, and engine torque at the maximum changes achieved. While the parameters studied in the exhaust gas emission test were the amount of $\mathrm{HC}$ and $\mathrm{CO}$ at stationary rotation. So far, the existing research and publications have been more dominant in testing PPO on diesel engines. For this reason, this test can determine the effect of the use of PPO when applied as fuel on a gasoline motor.

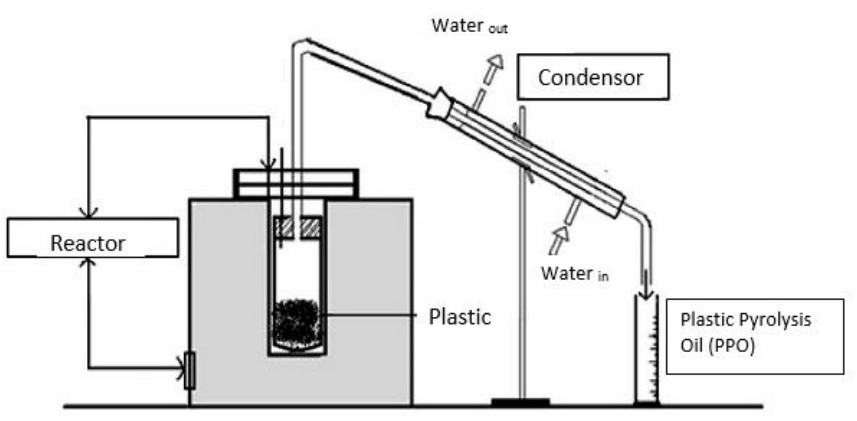

Figure 1: Plastic pyrolysis process.

\section{MATERIALS AND RESEARCH METHOD}

This research was carried out in four stages, namely the research preparation stage, the testing phase of plastic pyrolysis oil characteristics, the fuel testing stage of the engine, and the data analysis stage. The materials used were plastic waste from mineral water bottles for PET plastic types and plastic bags for LDPE plastic types. Testing of engine performance and exhaust gas emissions was carried out on a one-stroke four-cylinder motorized vehicle with a capacity of 100 ccs using plastic pyrolysis oil from PET, LDPE, and Pertamax type gasoline. The equipment used was in the form of Dynamometer Sportdyno V3.3 and Engine gas analyzer 4-Gas gasoline/ Model 10174175.

The process of utilizing plastic waste into fuel (Figure 1) with this pyrolysis method involved preparing plastic waste from PET and LDPE types, chopping, washing, and drying. The plastic material was put into a pyrolysis reactor at $350^{\circ} \mathrm{C}$ in a room without oxygen. The gas that came out of the reactor was then put into the condenser to obtain plastic pyrolysis oil (PPO). Testing the characteristics of oil properties included the heating value test, octane number, density test, kinematic viscosity test, and flash point test. 
Sunaryo et al., International Journal of Emerging Trends in Engineering Research, 7(11), November 2019, 454 - 459

The spark-ignition engine performance test and exhaust gas emissions (Figure 2) were carried out to find out how much influence the use of PPO on motor power, torque, and emissions. The motorcycle was placed and turned on the Dynamometer, then spontaneously accelerated from 4000 rpm to the maximum rotation of the motor for ten seconds. On the measuring panel, a graph showing the amount of power, torque of the motor would be seen. The testing of exhaust gas emissions was then carried out using a gas analyzer. The motorcycle was turned on with a measuring probe inserted at the exhaust tip. Raised and held the engine speed to $4000 \mathrm{rpm}$ for at least five seconds and returned it to the stationary engine speed. Performed measurements of exhaust gas emissions with a duration of 20 seconds, then recorded the appointment of numbers on display or printed to find out the levels of $\mathrm{HC}, \mathrm{CO}, \mathrm{CO}_{2}$, and $\mathrm{O}_{2}$

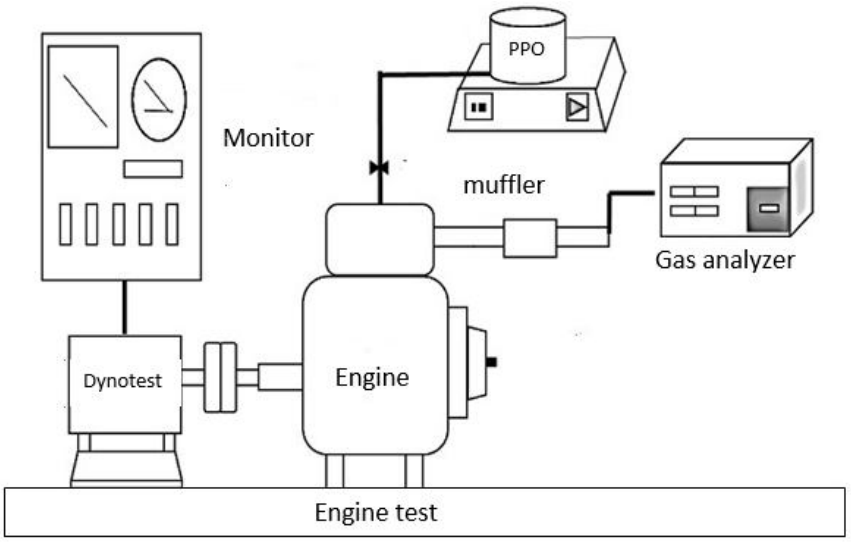

Figure 2: Testing tool layout.

\section{RESULTS AND DISCUSSION}

This section presents and discusses the experimental results of using pyrolysis plastic oil (PPO) from LDPE and PET plastic types from the spark-ignition engines. The testing was compared to gasoline fuel. The investigation focused on PPO property characteristics, engine performance, and exhaust gas emission analysis.

\subsection{Characteristics of Plastic Pyrolysis Oil (PPO)}

Testing the characteristics of PPO included RON, MON, heating value, kinematic viscosity, density, flash, and fire point. Based on Table 1 it shows that the characteristics of plastic pyrolysis oil are in the range of characteristics of gasoline fuels that are marketed in the community.

Table 1: Testing the PPO characteristic values

\begin{tabular}{lccc}
\hline \multicolumn{1}{c}{ Characteristics } & PET & LDPE & Gasoline \\
\hline $\begin{array}{l}\text { Heat Value }(\mathrm{MJ} / \mathrm{kg}) \\
\begin{array}{l}\text { Density in the } 15{ }^{\circ} \mathrm{C} \\
(\mathrm{gr} / \mathrm{ml})\end{array}\end{array}$ & 46.54 & 45.77 & 45.63 \\
$\begin{array}{l}\text { Viscosity kinematic } \\
\text { in the } 40{ }^{\circ} \mathrm{C}\left(\mathrm{mm}^{2} / \mathrm{s}\right)\end{array}$ & 0.851 & 0.7611 & 0.7492 \\
\end{tabular}

\begin{tabular}{lccc}
$\begin{array}{l}\text { Flash point \& Fire } \\
\text { point PMCC }\left({ }^{\circ} \mathrm{C}\right)\end{array}$ & $<21$ & $<24$ & $22-23[21]$ \\
Octane Number & 92.6 & 87.9 & $88-95[22]$ \\
\hline
\end{tabular}

Testing of the octane value of fuel (RON number) of liquid fuel from PET and LDPE plastic waste was carried out using a portable octane analyzer using the Zeltex method ASTM D 613. The magnitude of the RON value can be shown in table 1. The octane value of liquid fuel from waste PET plastic is equivalent to Pertamina's Pertamax type materials. It indicates that PPO, which is also a type of ethanol, can be used effectively for gasoline motors [23]. PPO ethanol has a high calorific value, octane number, flash, and fire point, and is similar to petrol, so it is very suitable to be used as a substitute for motor fuel.

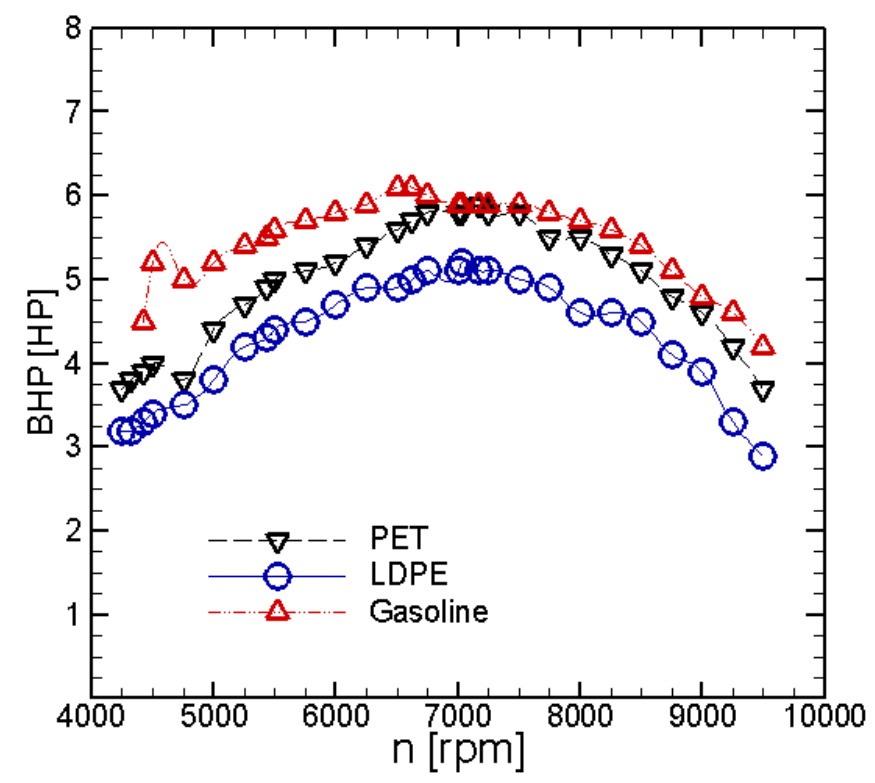

Figure 3: Relationship between engine speed and power.

\subsection{The Performance of The Motor Fuel}

Motor performance testing which included torque, power, and speed of increase of motor rotation. A comparison of the magnitude of motor power and motor torque was from each use of LDPE PPO fuel, PET PPO, and Pertamax gasoline. The relationship between motor speed and power can be shown in Figure 3. The test results show that the motor power for the use of PPO from PET type is 3.3\% lower, and PPO from LDPE type is $14.8 \%$ compared to Pertamax gasoline. Motor power from the use of PPO PET type is also higher than the LDPE type by $13.5 \%$. Where the maximum motor power for PPO PET type is $5.9 \mathrm{HP}$ at $7167 \mathrm{rpm}$, PPO LDPE type is 5.2 $\mathrm{HP}$ at $7030 \mathrm{rpm}$, and Pertamax gasoline is $6.1 \mathrm{Hp}$ at $6619 \mathrm{rpm}$ engine speed.

Testing of motor torque, as shown in Figure 4, shows that the maximum motor torque with fuel from PPO PET plastic is 6.77 $\mathrm{Nm}$ at $4317 \mathrm{rpm}$, PPO LDPE plastic is $5.77 \mathrm{Nm}$ at 5434 rpm, and Pertamax is $8.36 \mathrm{Nm}$ at $4428 \mathrm{rpm}$. The maximum 
Sunaryo et al., International Journal of Emerging Trends in Engineering Research, 7(11), November 2019, 454 - 459

motor torque of PPO PET types and LDPE type is $19.02 \%$ and $30.98 \%$ lower compared to Pertamax gasoline. PET PPO is better than LDPE PPO with maximum torque greater than $18.77 \%$. The motor torque for PPO is smaller compared to Pertamax gasoline, due to the lower heating value of PPO from Pertamax gasoline. Torque is strongly influenced by the amount of energy produced by combustion, which is influenced by the amount of heat in the fuel.

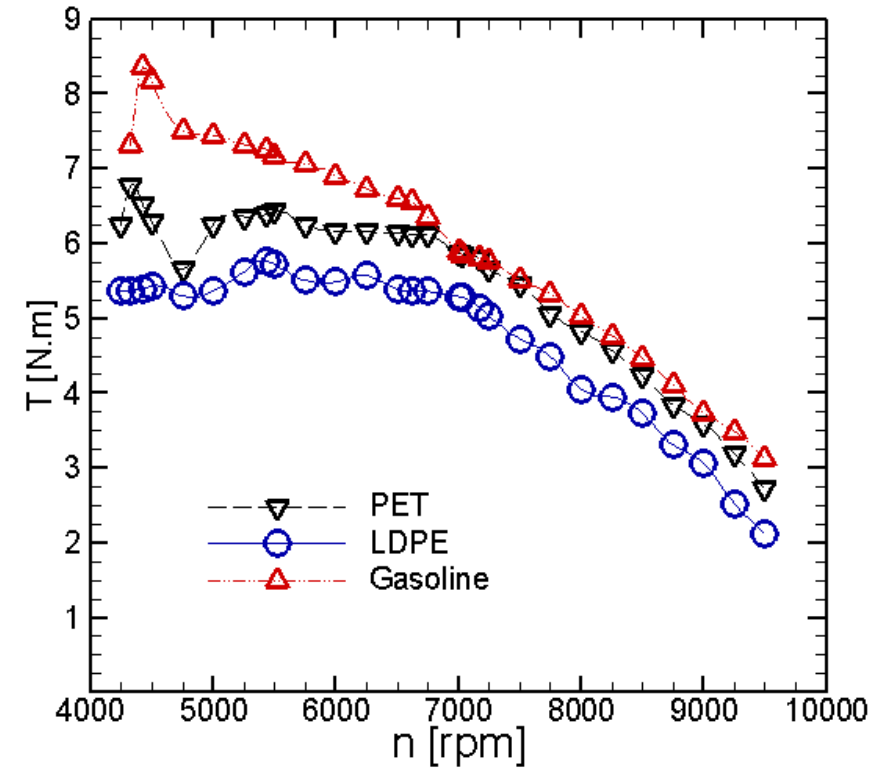

Figure 4: Relationship between engine speed and power

\subsection{Specific Fuel Consumption (SFC)}

Measurement of specific fuel consumption (SFC) is the ratio between the mass of fuel consumed by the engine and the power generated during a specific time. SFC value is very dependent on the power generated by the engine. Figure 5 presents the specific fuel consumption levels of various types of PPO use to Pertamax gasoline.

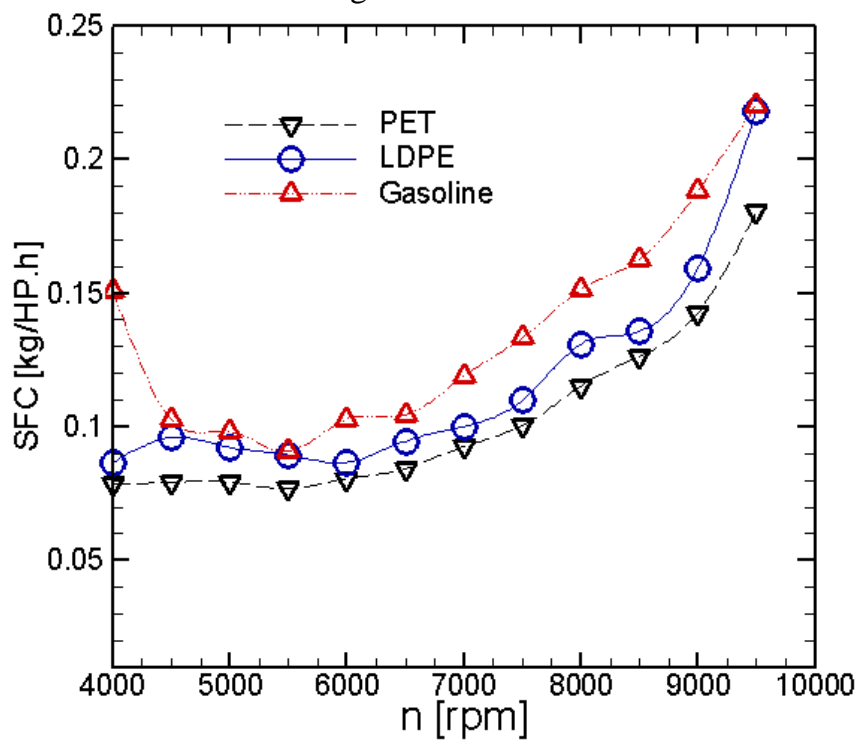

Figure 5: Relationship of engine rotation and specific fuel consumption
The use of plastic pyrolysis fuels can reduce fuel consumption or more efficiently. The specific fuel consumption for the type of gasoline Pertamax is an average of $0.1350 \mathrm{~kg} / \mathrm{HP}$.Hours, so the percentage of SFc reduction in each PPO type is PET by $32.5 \%$ and LDPE by $17.8 \%$. With the magnitude of the level of consumption of the smallest specific fuel is at $4000-5500$ rpm (medium speed). PPO from PET plastic type has proven to be more efficient compared to PPO of LDPE type.

\subsection{Exhaust Gas Emissions}

Exhaust gas emission testing is to measure the effect of the use of liquid plastic fuels on levels of exhaust gas emissions of a motor vehicle. Measurements were made at stationary rotation, which was $1500 \mathrm{rpm}$ that included levels of hydrocarbons (HC), carbon monoxide (CO), and lamda. A comparison of levels of exhaust gas emissions is shown in Figure 6.

Figure 6 is a comparison of exhaust gas emissions from each use of Pertamax fuel, PPO LDPE types, and PET types. HC levels for PPO LDPE types have the lowest emissions of 991 ppm, lower than PPO PET types of 1341 ppm, and Pertamax of $2504 \mathrm{ppm}$. Reducing HC emissions is by using PET PPO by $46 \%$ and LDPE PPO by $60 \%$. The average use of ethanol in gasoline engines is proven to be able to reduce emissions by $60 \%$ compared to gasoline fuels. Likewise, with CO levels, PPO LDPE plastics produce emissions of $3.70 \%$, PET PPO types of $5.25 \%$ better than Pertamax of $5.6 \%$. For non-hazardous gas content in PPO, it shows a higher concentration of carbon monoxide $\left(\mathrm{CO}_{2}\right)$. Vehicles powered by ethanol or ethanol-gasoline mixtures show a decrease in the concentration of $\mathrm{CO}$ and UHC (unburnt hydrocarbons), compared to gasoline [24].

The combustion process also occurs with a ratio of a mixture of fuel and air, which is relatively thin, with a value of lamda higher than one. The process of combustion of PPO fuel is more perfect in terms of higher $\mathrm{CO}_{2}$ levels and lower $\mathrm{O}_{2}$ levels. Regarding the value of the air-fuel ratio (lamda) in the combustion conditions of the motor, it can be concluded that the PPO fuel can be said to be more efficient.

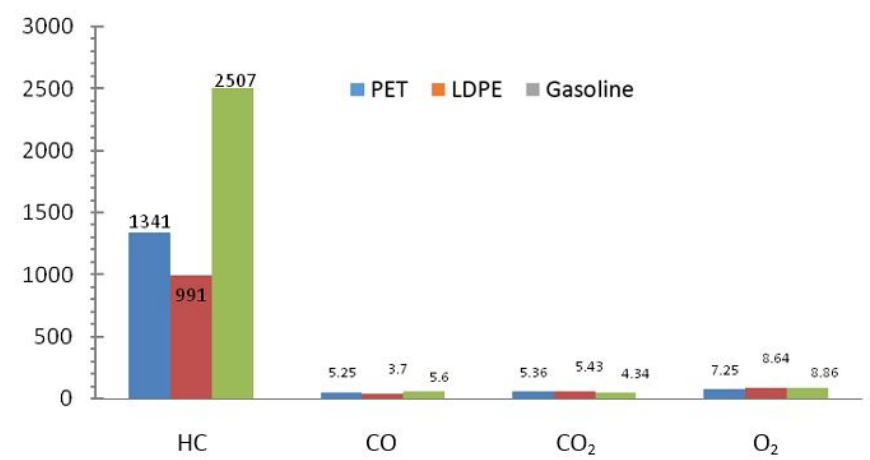

Figure 6: Comparison of exhaust gas emissions levels 
Sunaryo et al., International Journal of Emerging Trends in Engineering Research, 7(11), November 2019,454 - 459

\section{CONCLUSION}

An experimental investigation was carried out to analyze and understand the characteristics of property, performance, and emissions from a spark ignition (SI) engine fueled by pyrolysis plastic oil (PPO). Tests carried out on a $100 \mathrm{cc}$ one-cylinder four-stroke gasoline engine. The characteristics of PPO properties are similar to petrol/gasoline in terms of the heating value, and octane number, but the viscosity is higher. The performance of SI engines for PPO PET fuels is higher than PPO LDPE but lower than gasoline fuels. PPO also shows the consumption of specific fuels that are more efficient and levels of exhaust gas emissions that are lower. Therefore, PPO is very suitable to be used as an alternative fuel for SI engines.

\section{ACKNOWELDGEMENT}

Both the first and the second authors would like to acknowledge the financial from Indonesian Goverment in supporting the research through Universitas Muhammadiyah Surakarta under magister research project No. 199.10/A.3-III/LPPM/2019.

\section{REFERENCES}

1. M. Eswaramoorthi, T. Venkateshan, M. Bala and S. Gejendhiran. Review of Plastic Waste Management by Pyrolysis, in International Journal Research Application Science Engineering Technology, 2016, vol. 4, no. 11 , pp. 514-517.

2. S. Dayana, A. Sharuddin, F. Abnisa, W. Mohd and A. Wan. A review on pyrolysis of plastic wastes, Energy Conversion Managament, 2016, vol. 115, pp. 308-326. https://doi.org/10.1016/j.enconman.2016.02.037

3. I. Kalargaris, G. Tian and Sai Gu. Performance and emission analysis of a diesel engine using plastic pyrolysis oil, Fuel Process Technology, 2017, vol. 157, pp. 108-115.

https://doi.org/10.1016/j.fuproc.2016.11.016

4. H. Venkatesan, S. Sivamani, K. Bhutoria and H. H. Vora. Experimental study on combustion and performance characteristics in a DI CI engine fuelled with blends of waste plastic oil, Alexandria Engineering Journal, 2017, pp. 4-10.

https://doi.org/10.1016/j.aej.2017.09.001

5. R. K. Yadav and Y. K. Tembhurne. Waste Plastic Fuel Used in Petrol Engine, International Journal Mechanical Engineering Technology, 2016, vol. 7, no. 1, pp. 1-4.

6. V. Nindita. Studi Berbagai Metode Pembuatan BBM dari Sampah Plastik Jenis LDPE dan PVC dengan Metode Thermal \& Catalytic Cracking ( Ni-Cr / Zeolit ), Jurnal Teknis, 2015, vol. 10 no. 2, pp. 137-144.

7. D. Iswadi, F. Nurisa and E. Liastuti. Utilization of LDPE and PET Plastic Waste into Oil Fuel By
Pyrolysis Process, Jurnal Ilmiah Teknik Kimia, 2017, vol. 1, no. 2, pp. 11-17.

8. R. Kumar, M. K. Mishra, S. K. Singh and A. Kumar. Experimental evaluation of waste plastic oil and its blends on a single cylinder diesel engine, Journal Mechanical Science Technology, 2016, vol. 30, no. 10, pp. 4781-4789.

https://doi.org/10.1007/s12206-016-0950-7

9. M. A. Costagliola, L. De Simio, S. Iannaccone and M. V Prati. Combustion efficiency and engine out emissions of a SI. engine fueled with alcohol / gasoline blends, Applied Energy, 2012, pp. 1-10.

https://doi.org/10.1016/j.apenergy.2012.09.042

10. D. H. Qi and C. F. Lee. Combustion and emissions behaviour for ethanol - gasoline-blended fuels in a multipoint electronic fuel injection engine, International Journal of Sustainable Energy, 2014, vol. 35(4): pp.1-16.

11. C. Dardiotis, G. Fontaras, A. Marotta, G. Martini and U. Manfredi. Emissions of modern light duty ethanol flex-fuel vehicles over different operating and environmental conditions, FUEL, 2015, vol. 140, pp. 531-540.

12. T. J. Anup and V. Watwe. Waste Plastic Pyrolysis Oil as Alternative For SI and CI Engines, International Journal of Innovative Research in Science, Engineering, Technology, 2014, vol. 3, no. 7, pp. 14680-14687.

13. V. K. Kareddula and R. K. Puli. Influence of plastic oil with ethanol gasoline blending on multi cylinder spark ignition engine, Alexandria Engineering Journal, 2017.

https://doi.org/10.1016/j.aej.2017.07.015

14. A. Verma, A. Raghuvansi, M. A. Quraishi, J. V Tirkey and C. Verma. Engine Fuel Production from Waste plastic Pyrolysis ( WPO ) and Performance Evaluation in a CI engine with Diesel Blend, Journal Material and Environmental Science, 2018, vol. 2508, no. 6, pp. 1712-1721.

15. A. S. Olufemi and S. A. Olagboye. Thermal conversion of waste plastics into fuel oil, International Journal of Petrochemical Science \& Engineering, 2017, vol. 2, no. 8, pp. 252-257.

16. R. Miandad, M. A. Barakat, A. S. Aburiazaiza, M. Rehan, I. M. I. Ismail, and A. S. Nizami. International Biodeterioration \& Biodegradation Effect of plastic waste types on pyrolysis liquid oil Kingdom of Saudi Arabia, International Biodeterioration and Biodegradation, 2016, no. 0964-8305, pp. 1-14.

17. I. Kalargaris, G. Tian and S. Gu. Experimental evaluation of a diesel engine fuelled by pyrolysis oils produced from low-density polyethylene and ethylene - vinyl acetate plastics, Fuel Processing Technology, 2017, vol. 161, pp. 125-131. https://doi.org/10.1016/j.fuproc.2017.03.014

18. M. Sogancioglu, G. Ahmetli and E. Yel. Comparative Study on Waste Plastics Pyrolysis Liquid Products 
Sunaryo et al., International Journal of Emerging Trends in Engineering Research, 7(11), November 2019, 454 - 459

Quantity and Energy Recovery Potential, Energy Procedia, 2017, vol. 118, pp. 221-226.

19. R. Thomas, M. Sreesankaran, J. Jaidi, D. M. Paul and P. Manjunath. Experimental evaluation of the effect of compression ratio on performance and emission of SI engine fuelled with gasoline and $n$-butanol blend at different loads ${ }_{\varsigma}$, Perspectif in Science, 2016, vol. 8, pp. 743-746.

https://doi.org/10.1016/j.pisc.2016.06.076

20. D. Pradhan, H. Bendu, R. K. Singh and S. Murugan. Mahua seed pyrolysis oil blends as an alternative fuel for light-duty diesel engines, Energy, 2016, pp. 1-13. https://doi.org/10.1016/j.energy.2016.10.091

21. A. Raja and A. Murali. Conversion of Plastic Wastes into Fuels, Journal of Materials Science and Engineering, 2011, vol. 1, pp. 86-89.

22. S.D. A. Sharuddin, F. Abnisa, W. M. A. W. Daud and M. Karoua. Pyrolysis of plastic waste for liquid fuel production as prospective energy resource, IOP Conference Series: Materials Science and Engineering, 2018, vol. 334 pp 1-8.

https://doi.org/10.1088/1757-899X/334/1/012001

23. Y. Sekmen and T. Topgu. The effects of ethanol unleaded gasoline blends on engine performance and exhaust emissions in a spark-ignition engine, Renewable Energy, 2009, vol. 34/10, pp. 2101-2106. https://doi.org/10.1016/j.renene.2009.01.018

24. A. Elfasakhany. Investigations on the effects of ethanol e methanol e gasoline blends in a spark-ignition engine: Performance and emissions analysis, Engineering Science and Technology an International Journal, 2015, vol. 18, no. 4, pp. 713-719.

https://doi.org/10.1016/j.jestch.2015.05.003 